\title{
INTERNAL COMBUSTION ENGINE WITH COMBINED VALVE FOR BOTH INTAKE AND EXHAUST
}

\section{ONDŘEJ BOLEHOVSKÝ}

Czech Technical University in Prague, Faculty of Mechanical Engineering, Technická 4, 16607 Prague 6, Czech Republic e-mail: ondrej.bolehovsky@fs.cvut.cz

\section{SHRNUTí \\ Práce se zabývá počítačovou simulací nekonvenčního čtyřdobého motoru v 1-D komerčním kódu. Tento spalovací motor využivá pouze jeden ventil pro sání i výfuk, což prinnáší jisté výhody, které jsou však vykoupeny určitými problematickými vlastnostmi. Cílem této studie je zhodnotit potenciál tohoto motoru pomocí porovnání s konvenčním spalovacím motorem s víceventilovou hlavou válců. Dále je v této práci vyšetřen způsob přeplňování pomocí tlakových pulsů výfukových plynů v případě víceválcového uspořádání. Tento spalovací motor je zhodnocen z hlediska jeho využití jako prodlužovače dojezdu elektrických automobilů. \\ KLIČCVÁ SLOVA: NEKONVENČNI ČTYY̌d OBÝ SPALOVACI MOTOR, PRSTENCOVÝ VENTIL, SPOLEČNÝ VENTIL, PŘEPLŇOVÁNÍ POMOCI TLAKU VÝFUKOVÝCH PLYNŮ, LADĚNÉ VÝFUKOVÉ POTRUBÍ, I-D MODEL}

\section{ABSTRACT}

This work concerns the computer simulation of an unconventional 4-stroke cycle engine in a commercial 1-D code. The engine uses only one valve for both intake and exhaust. This brings some benefits, but also gives rise to some problematic issues. The aim of this study is to assess the potential of such an engine by comparing it with an engine that uses a conventional multi-valve cylinder head. Supercharging by means of exhaust gas pressure pulses in a multi-cylinder layout is investigated. Utilization of such an engine as a range extender unit for electric vehicles is assessed.

KEYWORDS: UNCONVENTIONAL 4-STROKE ENGINE, RING-SHAPED VALVE, SINGLE VALVE, SUPERCHARGING BY EXHAUST GASES, TUNED EXHAUST MANIFOLD, 1-D MODEL

\section{INTRODUCTION}

Since electric vehicles equipped with batteries cannot meet all the demands required by customers, car manufacturers have started adding an internal combustion engine to the drivetrain of an electric car as a generator to produce electricity for the electric traction motor. Such an engine extends the driving range of the electric vehicle and provides a reliable source of energy. It thus partly substitutes batteries that suffer from low energy density and decreasing capacity during cold periods. Such vehicles are termed "Extended Range Electric Vehicles" (E-REV) and the combustion engine unit is called a "Range Extender".

However, a "Range Extender" unit must meet certain criteria. It should be a small, light, powerful, cheap, economic and low emission unit with quick response to full load. This favors small gasoline engines that can be optimized for operation at certain engine speed modes. The very popular downsizing option brings high specific power output while maintaining favorable fuel consumption. However, these downsized engines usually use a turbocharger or a supercharger, which constitutes another big, heavy and expensive engine part. In the case of a turbocharger, "turbo lag" also brings disadvantages in terms of poor response time to full load.

There are insufficient ways for selecting the best solution for this application, since the internal combustion engine itself has been almost perfectly designed and optimized. Another approach is to explore some unconventional designs. Such a solution using a single combined valve for both intake and exhaust has recently been patented by the Czech Technical University and Knob Engines s.r.o. It features exceptional flow parameters of the cylinder head, the ability to use exhaust gas pressure pulses for direct supercharging and the disadvantage of a narrow engine speed range due to the 

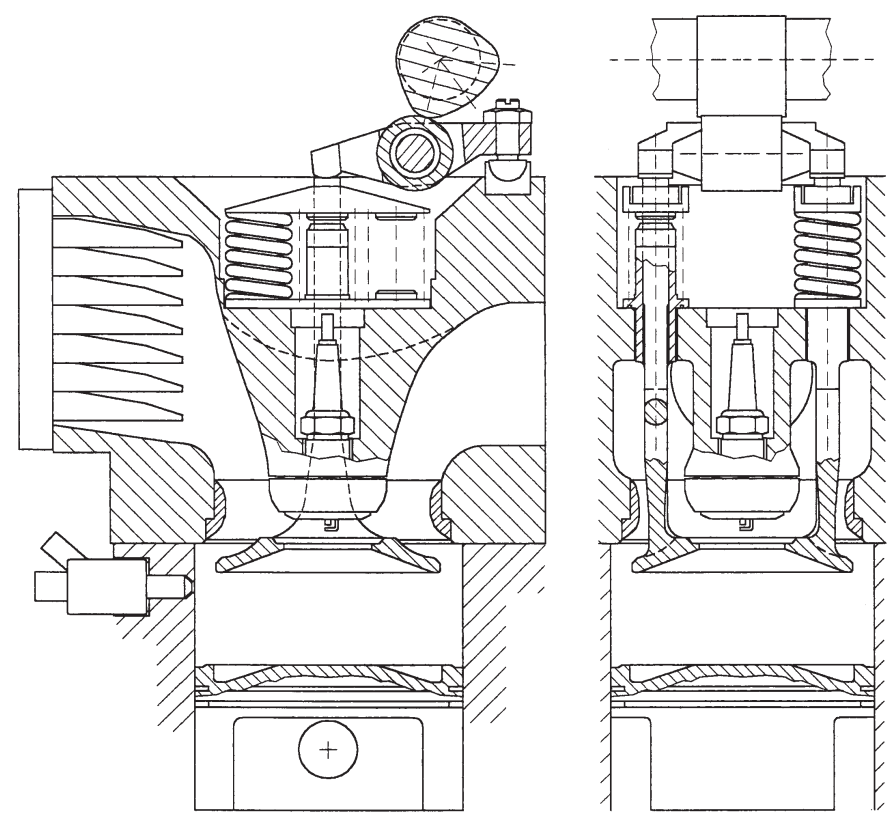

FIGURE 1: Cylinder head with ring-shaped valve

OBRÁZEK 1: Hlava motoru s prstencovým ventilem

nature of supercharging. These features make such an engine suitable for investigation as to whether it can be used as a range extender or not. However, this unconventional design incorporates certain problematic features that result from the gas exchange process by means of a single valve and port, and they will also be discussed in this study.

\section{DESCRIPTION: CYLINDER HEAD WITH RING-SHAPED VALVE}

The patented solution uses one valve and one shared port in the shape of a ring. The ring-shaped valve has two concentric sealing surfaces and an outer and inner valve seat is built into the cylinder head. The first patent [5] covers the manner of sealing of these two surfaces of the ring-shaped valve. The inner valve seat is spring loaded and uses the in-cylinder pressure to press it against the ring-shaped valve. A simple cross-sectional view of the cylinder head is depicted in Figure 1.

The free space in the middle of the valve can then be used for placing either a spark plug or injection nozzle, or both. This is why the ring-shaped valve must have two valve stems. Maximum flow rates are reached at lifts that are comparable with conventional four valve cylinder heads, so the acceleration is the same. Nevertheless, the mass of such a valve is significantly higher, so more springs or a desmodromic valvetrain has to be used. Figure 2 presents a comparison of the flow rates in the ring-shaped valve cylinder head and in a conventional multi- valve cylinder head of the same bore diameter in the intake direction. The lift curve of the ring-shaped valve for a spark ignited engine can be seen in Figure 5 .

Since the ring-shaped valve serves as a combined intake and exhaust valve, there must be an additional valve that separates the intake and exhaust phase. Therefore, a reed valve is placed at the end of the intake pipe (see Figures 1 and 3 on the left side). This solution keeps the exhaust port opened during the whole four-stroke period and thus enables the use of the blowdown pressure pulse of neighboring cylinders for direct supercharging. This phenomenon is described in the second patent [4] relating to this engine and the manner of the supercharging of a 2-cylinder engine can be seen in Figure 3 (clarified in subchapter 3.2).

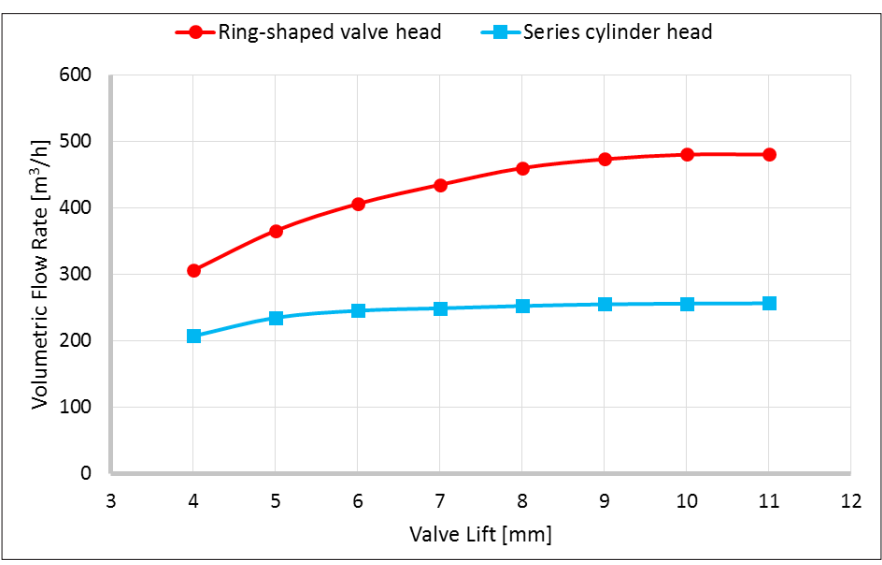

FIGURE 2: Flow characteristic of cyl. head - intake direction (cyl. bore $\varnothing 77 \mathrm{~mm}$ ) OBRÁZEK 2: Průtokové parametry hlavy válců ve směru sání (vrtání $077 \mathrm{~mm}$ )

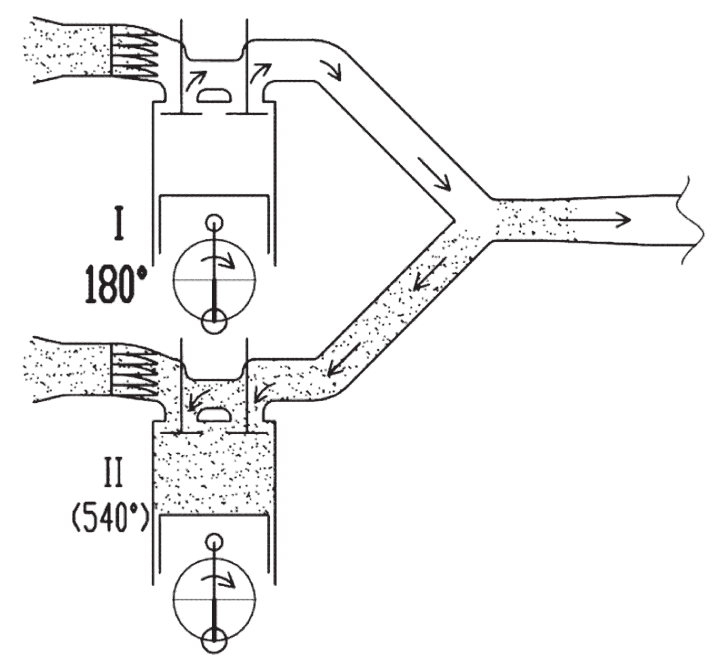

FIGURE 3: Method of supercharging a 2-cylinder engine OBRÁZEK 3: Způsob přeplňování dvouválcové varianty 
Of course, the above-mentioned features of the cylinder head also result in some problematic issues that must first be examined by means of numerical simulation (GT-Power) to assess the benefits that such a design could bring.

\section{RESULTS OF SIMULATION OF THE ENGINE}

A 1-D model of an engine with the ring-shaped valve cylinder head was constructed in the commercial 1-D code GT-Power. Based on the assumption that the engine could serve as a range extender, a naturally aspirated spark ignition version was chosen for the simulations. Since the ring-shaped valve cylinder head is assumed to enable direct supercharging by means of exhaust pressure pulses from neighboring cylinders, in addition to a one cylinder version, it was also necessary to select two and three cylinder versions for simulation. Cylinder dimensions were based on a bore diameter (ø77), for which the cylinder head was initially manufactured and its flow rates measured. The cylinder displacement was set to $250 \mathrm{~cm}^{3}$. Due to the fact that the exhaust port is without any additional valve, the engine must always be equipped with direct injection to prevent leakage of fuel into the exhaust pipe. Simulations were carried out at steady states for engine speed ranging from 6000 to $2000 \mathrm{~min}^{-1}$, at full load conditions (wide open throttle).

The body of the cylinder head with the ring-shaped valve constitutes a letter $T$ - the horizontal continuous pipe represents the intake and exhaust port, and the perpendicular pipe represents the shared annular port, to which the ringshaped valve is connected. A simple flow split object (in the shape of a letter T) was substituted for this cylinder head body in GT-Power. This substitution does not take into account the real geometry of the cylinder head body and it could be a possible source of inaccuracy. Object "Reed Valve" was placed in the intake manifold with features such as stiffness, mass and pre-tension. This component had to be properly optimized.

Since this unconventional engine is particularly sensitive to exhaust backpressure, simulations were carried out at first on the unrestricted configuration (without exhaust backpressure) and then with restricted exhaust manifold (by means of a multi-pipe object substituting the catalyst). For both versions the exhaust pipe geometry had to be individually optimized. The value of exhaust backpressure was set to 30 $\mathrm{kPa}$ at $6000 \mathrm{~min}^{-1}$, but in the case of the 2-cylinder version, the engine could not withstand more than $22 \mathrm{kPa}$.

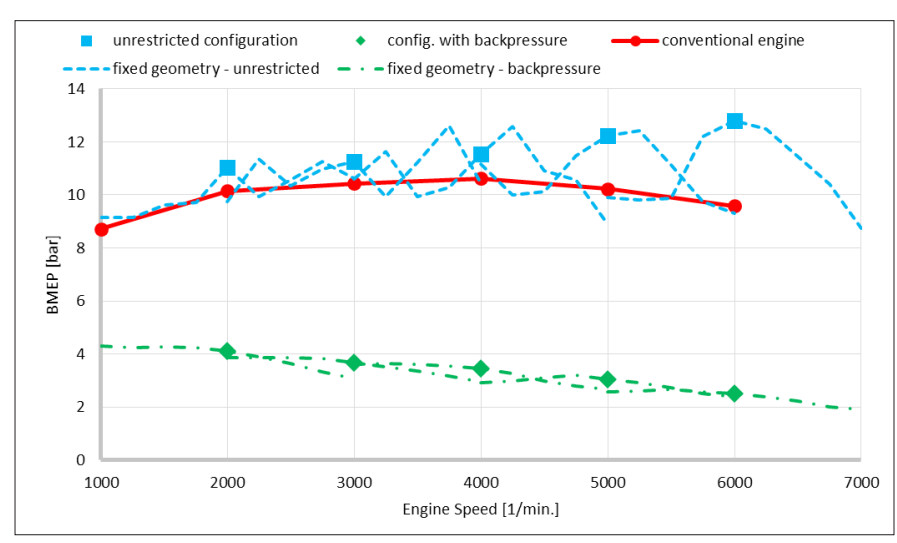

FIGURE 4: Full load characteristic of the 1-cylinder engine OBRÁZEK 4: Vnější charakteristika jednoválcové variatny

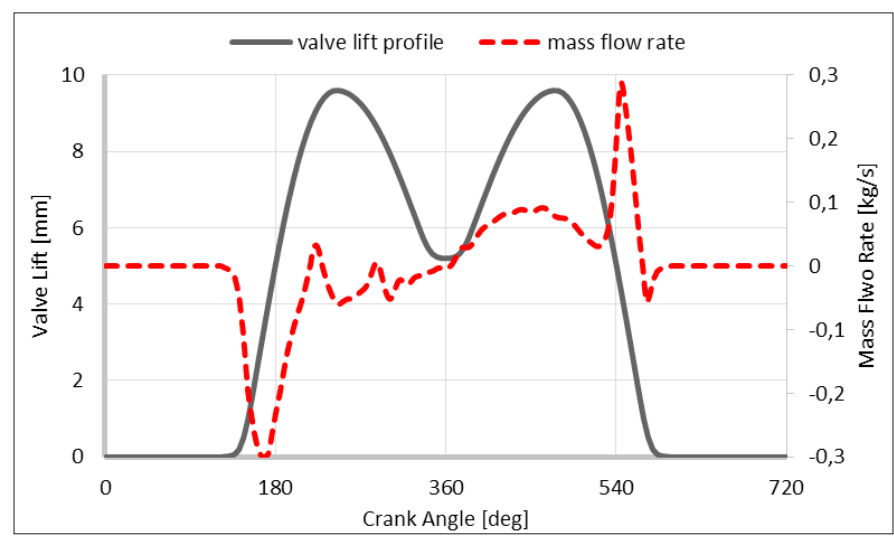

FIGURE 5: Ring-shaped valve lift curve and the mass flow rate through it for 2-cylinder version

OBRÁZEK 5: Zdvih a průtok prstencovým ventilem pro dvouválcovou variantu

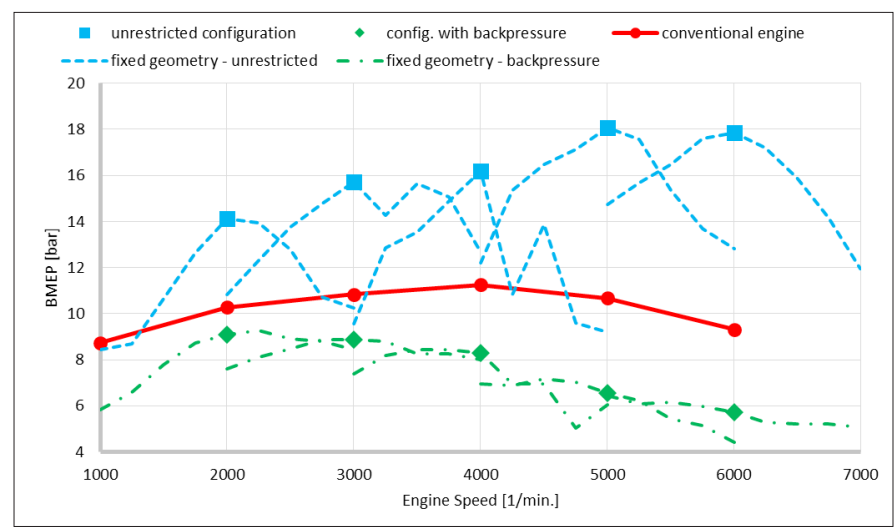

FIGURE 6: Full load characteristic of 2-cylinder engine OBRÁZEK 6: Vnější charakteristika dvouválcové varianty 


\subsection{1-CYLINDER LAYOUT}

Figure 4 shows the brake mean effective pressure (bmep) with respect to engine speed of the 1-cylinder version for the unrestricted configuration and also for the configuration with pressure loss at the exhaust side. Exhaust pipe geometry at every single engine speed point is individually optimized, and in particular the length of the exhaust pipe. It is clear that adding any backpressure at the exhaust side decreases the otherwise good performance (up to 13 bar), in some cases by about 8 bar of bmep. This results from the higher percentage of burned gas caused by bad scavenging of the shared space in the cylinder head. The same engine with a conventional cylinder head gives better results in this case (Figure 4). The performance of the unrestricted configuration is about $20 \%$ better than the conventional engine, which is due just to the exceptional flow parameters of the cylinder head. The dashed and dash-and-dot lines represent the behavior of bmep in the vicinity of optimized engine speed points with fixed exhaust pipe geometry for the unrestricted and restricted configurations respectively. Sensitivity to engine speed change is significant for the unrestricted configuration at higher engine speed, while the restricted one has a flat torque curve.

\subsection{2-CYLINDER LAYOUT}

This version enables the use of the exhaust gas pressure pulses of one cylinder to supercharge the other cylinder. Mass flow rate through the ring-shaped valve in Figure 5 clearly shows the supercharging method - at the end of the intake stroke, the pressure pulse from the other, supercharging, cylinder (the valve of which is just opening) pushes the fresh air, which has been drawn into the space above the valve, directly into the supercharged cylinder. Thus the mass flow rate through the ring-shaped valve at the valve closing increases. This repeats for the other cylinder as well. This behavior is conditioned by a suitable length of the exhaust branches (before the exhaust pipes joint), so that the pressure pulse comes at the right time and the space above the valve is well scavenged.

Thus bmep of the 2-cylinder version is exceptional at individually optimized engine speed points for the unrestricted configuration, as depicted in Figure 6. It reaches a bmep of $18 \mathrm{bar}$, which is a value comparable to that of a turbocharged engine. The configuration with exhaust backpressure, shown in the same figure, again decreases these values almost by half, especially at higher engine speeds, where the backpressure is also higher. Moreover, in this case the engine could not withstand a higher exhaust backpressure than $22 \mathrm{kPa}$ at $6000 \mathrm{~min}^{-1}$. Bmep sensitivity to the engine speed

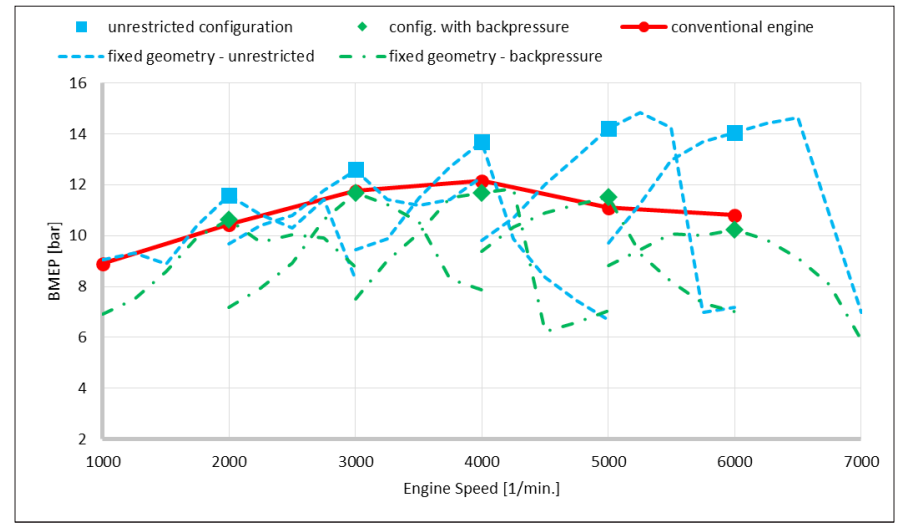

FIGURE 7: Full load characteristic of 3-cylinder engine OBRÁZEK 7: Vnější charakterstika tříválcové varianty

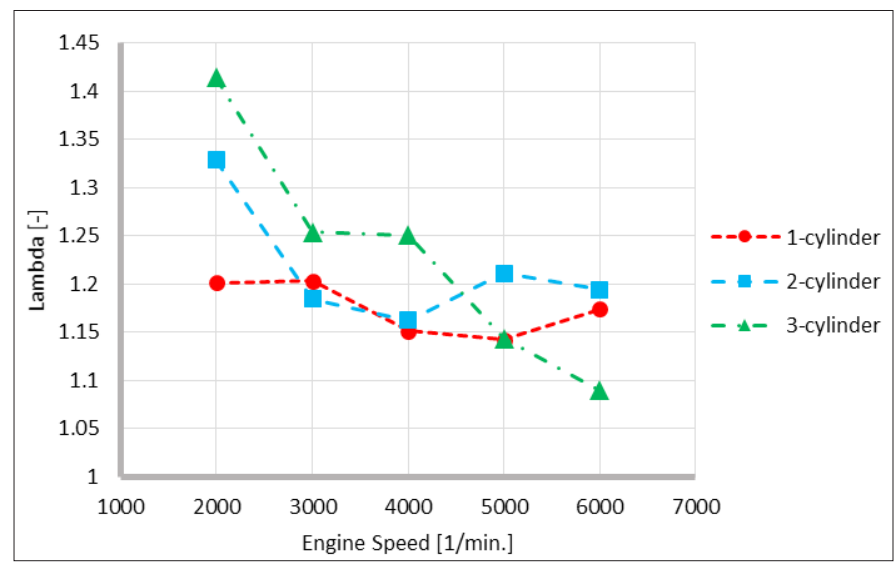

FIGURE 8: Air-fuel eq. ratio in the exhaust tail pipe OBRÁZEK 8: Součinitel přebytku vzduchu ve výfuku

change for the fixed exhaust pipe geometry in the vicinity of optimized engine speed points is also shown in Figure 6. The sensitivity in the case of the restricted configuration is not as significant as for the unrestricted one.

\subsection{3-CYLINDER LAYOUT}

For the unrestricted configuration, the 3-cylinder version gives a bmep about 4 bar lower than the 2-cylinder one (as shown in Figure 7), because it requires much longer exhaust pipes due to the shorter firing intervals $\left(240^{\circ}\right)$ and due to the fact that the pressure pulse splits into two exhaust pipes. However, this version is the best at withstanding the exhaust backpressure. When compared to the conventional multi-valve cylinder head conception, the ring-shaped valve cylinder head conception has at individually optimized engine speed points almost the same performance as the conventional one, which has a bmep ranging from 10 to 12 bar. Performance in the 


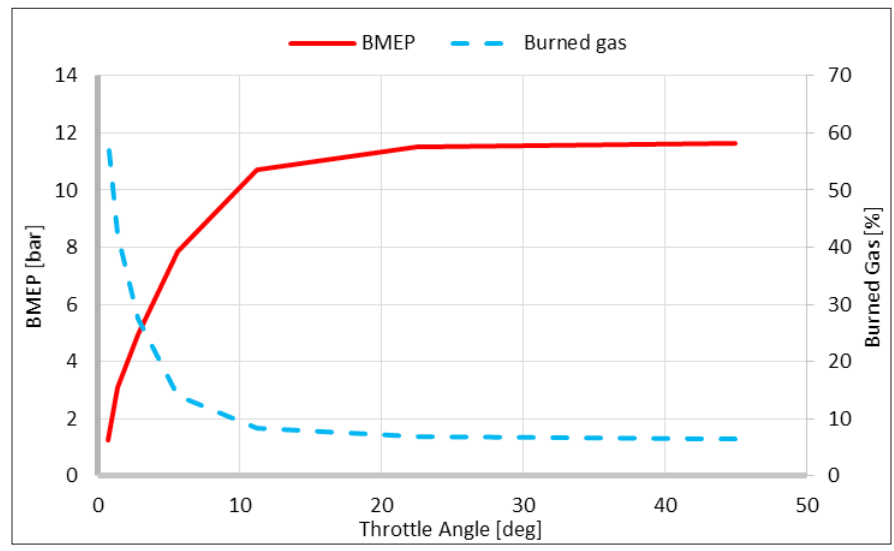

FIGURE 9: Part load for 2-cyl. configuration at $4000 \mathrm{~min}^{-1}$ OBRÁZEK 9: Částečné zatí̌zení pro dvouválcovou variantu při 4000 $\min ^{-1}$

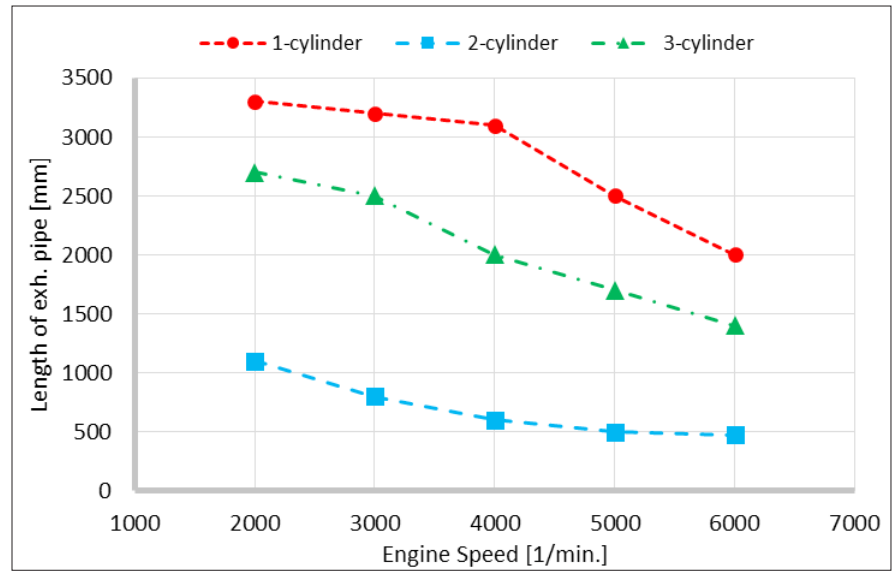

FIGURE 10: Optimized exhaust pipe lengths at individual engine speed points

OBRÁZEK 10: Optimalizovaná délka výfukového potrubí v jednotlivých otáčkových bodech

vicinity of optimized engine speed points for fixed exhaust pipe geometry goes down more rapidly on either side of the optimal point also in the case of the restricted configuration, which degrades the otherwise favorable performance.

The three cylinder concept is more suitable for higher engine speeds, at which the exhaust pipes do not have to be too long and the engine achieves very good performance even at high engine speed due to the exceptional flow parameters of the ring-shaped valve.

\section{PROBLEMATIC FEATURES OF THE ENGINE}

In addition to exhaust backpressure, another problematic issue of the simulated concept is the high amount of fresh unburned air in the exhaust manifold, which is necessary for scavenging the shared space above the ring-shaped valve. Therefore, it is not possible to use the three-way catalyst in the case of spark ignited engines with stoichiometric mixture. The amount of fresh unburned air for the restricted configuration is shown in Figure 8 by means of air-fuel equivalence ratio $\lambda$ (this does not correspond to air-fuel ratio in the cylinder, which is $\lambda=1$ ). It is obvious that a significant amount of unburned air bypasses the engine. For the unrestricted configurations, the amount is an order of magnitude higher.

A problem, common for both restricted and unrestricted configurations, is part load operation. Throttling in the intake manifold results in such a high percentage of burned gas in the cylinder that the mixture would not be ignitable. This issue is shown in Figure 9 for the 2-cylinder version at $4000 \mathrm{~min}^{-1}$. This need not be an issue for engines that do not operate with stoichiometric mixtures.

The required exhaust pipe length might constitute a design and emission aftertreatment problem. As shown in Figure 10, the one and two-cylinder versions in particular require very long pipes which do not enable the placing of aftertreatment systems at a reasonable distance from the engine (for fast warm up).

\section{CONCLUSION}

The above results for performance indicate that an engine equipped with the ring-shaped valve cylinder head is unable to compete with conventional engines in applications related to extended range electric vehicles. The main reason for this is the necessity of using exhaust gas aftertreatment systems which create significant backpressure in the exhaust manifold, which the patented conception cannot cope with. Moreover, this is backed up by the fact that extended range electric vehicles are intended to be clean vehicles and the emission requirements, and thus exhaust backpressure, would even increase.

The potential of the engine does not lie in applications for passenger vehicles, which have to comply with strict emission regulations. Racing and aerospace applications are areas where exhaust emissions and noise are not so strictly restricted, and there could be the potential for using such an engine after resolving other problematic issues, such as part load operation. 


\section{ACKNOWLED GEMENTS}

This work was supported by the Grant Agency of the Czech Technical University in Prague, grant No. SGS13/184/

OHK2/3T/12.

This research has been realized using the support of Technological Agency, Czech Republic, programme Centres of Competence, project \# TE01020020 Josef Božek Competence Centre for Automotive Industry.

This research has been realized using the support of EU Regional Development Fund in OP R\&D for Innovations (OP VaVpl) and Ministry for Education, Czech Republic, project \# CZ.1.05/2.1.00/03.0125 - ED2.1.00/03.0125 Josef Božek Research Centre for Vehicles of Sustainable Mobility.

This support is gratefully acknowledged.

\section{REFERENCES}

[1] GAMMA TECHNOLOGIES, INC. Flow Theory Manual, 2009

[2] GAMMA TECHNOLOGIES, INC. GT-Power - User's Manual, 2009

[3] MACEK, J. Spalovací motory I., Praha, ČVUT, 2007

[4] KNOB, V., BOLEHOVSKÝ, O.: Víceválcový spalovací motor s využitím tlaku výfukových plynů k zvýšení naplnění válcủ. 2012. Patent CZ 303350 B6

[5] KNOB, V.: Hlava válce spalovacího motoru s prstencovým ventilem. 2012. Patent CZ 303732 B6

[6] ANUPAM, D., Development of a Reed Valve Model for Engine. SAE Technical Paper Series [online]. 2004, No. 2004-01-1455

[7] Company documents of Knob Engines, s. r. 0. 